\title{
Diagnostic value of nine nucleic acid amplification test systems for Mycobacterium tuberculosis complex
}

\author{
Gülnur Tarhan', Salih Cesur², Hülya Şimşek³ Ismail Ceyhann', Yusuf Ozay ${ }^{5}$, Melike Atasever ${ }^{4}$ \\ ${ }^{1}$ Adryaman University, Faculty of Medicine, Department of Medical Microbiology, Adiyaman, Turkey \\ ${ }^{2}$ Ankara Training and Research Hospital, Department of Infectious Diseases, Ankara, Turkey \\ ${ }^{3}$ National Public Health Institution, National Tuberculosis Reference Laboratory, Ankara, Turkey \\ ${ }^{4}$ Atatürk Chest Diseases and Thoracic Surgery Training and Research Hospital, Microbiology Laboratory, Ankara, Turkey \\ ${ }^{5}$ Adiyaman University, Faculty of Medicine, Department of Medical Biology, Adiyaman, Turkey.
}

\begin{abstract}
Objective: In this study, nine commercial Nucleic Acid Amplification Test Systems (NAATs) were evaluated for diagnostic performance of Mycobacterium tuberculosis complex (MTBC) from smear positive sputum species (SPss) and smear negative sputum specimens (SNss).

Methods: Sixty SPss and 55 SNss were examined microscopically by Ehrlich Ziehl Neelsen (EZN) staining method, and also inoculated on Löwenstein Jensen (LJ) medium for culture. The sensitivity and specificity of nine NAATs were calculated according to $\mathrm{LJ}$ culture method accepted as gold standard.

Results: When LJ culture results were taken as gold standard; the sensitivity rates of method COBAS Amplicor MTB (Method A), GenProbe MTD (Method B), Cobas TaqMan MTB PCR (Method C), iCycler iQ RT PCR (Method D), TaqMan PCR AB 5700 (Method E), TaqMan PCR AB7700 (Method F), LightCycler ${ }^{\circledR} 480$ RT PCR (Method G), Rotor Gene RT PCR (Method H) and the AdvanSure TB/NTM RT PCR (Method I) for SPss were $98.3 \%, 93.3 \%, 96.7 \%, 100 \%, 93.3 \%, 100$ $\%, 100 \%, 100 \%$ and $100 \%$, respectively. The sensitivity was $53.84 \%$ for the methods $A, B, D, E, G$ and I; $38.46 \%$ for the method $\mathrm{C}$ and $\mathrm{H} ; 61.5 \%$ for the method $\mathrm{F}$ for the method $\mathrm{I}$ in $\mathrm{SNss}$. There were no statistical significant differences between the nine NAATs $(p \geq 0.05)$. The specificity was $100 \%$ for all nine NAATs in SNss. The positivity rates of methods were $53.8 \%$ for methods $A, B, D, E, G, I ; 38.5 \%$ for methods $C$ and $H$, and $61.5 \%$ for method $F$ in $S N s s$. These rates were $100 \%$ for $D, F, G, H$ and $; ; 98.3 \%$ for method $A ; 96.7 \%$ for method $C ; 93,3 \%$ for methods B and E in SPss. Statistical analysis showed that there was no statistically significant differences among the nine NAATs $(p \geq 0.05)$.
\end{abstract}

Conclusion: It is concluded that the nine NAATs might be useful for detecting MTBC from SPss, but not effective for SNss. J Microbiol Infect Dis 2015;5(3): 103-109

Key words: Tuberculosis, polymerase chain reaction, nucleic acid amplification test, smear positive, smear negative, sputum

\section{Mycobacterium tuberculosis kompleksinin saptanmasında dokuz farklı nükleik asit amplifikasyon yönteminin tanısal değeri}

\section{ÖZET}

Amaç: Bu çalışmada, yayma pozitif balgam örneklerinde ve yayma negatif balgam örneklerinde Mycobacterium tuberculosis kompleks (MTBK)'nin hızı tanısında dokuz ticari Nükleik Asit Amplifikasyon Test sistemi (NAAT)'nin tanı performansı değerlendirildi.

Yöntemler: Çalışma sırasında kullanılan 60 yayma pozitif ve 55 yayma negatif balgam örneği mikroskopik olarak Erlich Zielh Neelsen (EZN) boyama yöntemi ve Löwenstein Jensen (LJ) besiyerinde kültür ile değerlendirildi. Löwenstein-Jensen kültür yöntemi altın standart olarak kabul edilerek dokuz NAAT yönteminin duyarlıık ve özgüllükleri hesaplandı.

Bulgular: Löwenstein Jensen kültür sonuçları altın standart olarak alındığında; Yayma pozitif örneklerde (COBAS Amplicor MTB (Metot A), GenProbe MTD (Metot B), Cobas TaqMan MTB PCR (Metot C), iCycler iQ RT-PCR (Metot D), TaqMan PCR AB 5700 (Metot E), TaqMan PCR AB7700 (Metot F), LightCycler ${ }^{\circledR} 480$ RT PCR (Metot G), Rotor Gene RT PCR (Metot

Correspondence: Salih Cesur, Ankara Training and Research Hospital, Clinic of Infectious Diseases and Clinical Microbiology, 
H) ve AdvanSure TB/NTM RT PCR (Metot I) yöntemlerinin duyarlılık oranı sırası ile \% 98,3, \% 93,3, \% 96,7, \% 100, \% 93,3, $\%$ 100, \% 100, \% 100 ve \% 100 olarak bulundu. Bu oran yayma negatif örneklerde A, B, D, E, G ve I yöntemleri için \% 53,8; C ve H yöntemi için \% 38,5; F yöntemi için \% 61,5 olarak bulundu. Dokuz NAAT metodu arasında istatistiksel olarak anlamlı fark bulunmadı. ( $p \geq 0.05$ ). Yayma negatif balgam örneklerinde özgüllük bütün NAAT yöntemleri için \% 100 olarak saptandı. Pozitif saptama oranı yayma negatif örneklerde A, B, D, E, G ve I yöntemleri için \% 53,8, C ve H yöntemleri için \% 38,5 ve F yöntemi için \% 61,5 olarak bulundu. Bu oran yayma pozitif balgam örneklerinde $D, F, G$, H ve I yöntemleri için \% 100; A yöntemi için \% 98,3, C yöntemi için \% 96,7, B ve E yöntemleri için \% 93,3 olarak saptandı. Dokuz NAAT yöntemi arasında istatistiksel olarak anlamlı fark bulunmadı $(p \geq 0.05)$.

Sonuç: Dokuz NAAT yönteminin yayma pozitif örneklerde MTBK tanısında yararlı olabileceği, ancak yayma negatif örneklerde etkin olmadığı sonucuna varıldı.

Anahtar kelimeler: Tüberküloz, polimeraz zincir reaksiyonu, nükleik asit amplifikasyon test, yayma pozitif, yayma negatif

\section{INTRODUCTION}

Tuberculosis (TB) is a life-threatening infectious disease, and one of the leading bacterial agents affecting to pulmonary system all over the world as well as in Turkey. ${ }^{1}$ According to the World Health Organization's records, TB incidence in Turkey in 2009 was $25 / 100,000$ with a mortality rate of 5 persons per 100,000 inhabitants, has a TB incidence of about $29 / 100,000$, which is lower than WHO European region. ${ }^{1,2}$ Smear microscopy is the cheapest, easiest and most rapid method for detection of mycobacteria from clinical specimens. However; it lacks specificity and low sensitivity (50\%-70\%) for pulmonary TB. ${ }^{3,4}$ Culture techniques are more sensitive than smear microscopy. Culture techniques have high sensitivity and antimicrobial susceptibility test can be done to the strain which was isolated after culturing. ${ }^{4-9}$

Although culturing is a certain method for diagnosis, pathogen mycobacteria usually grow slowly and the earliest reproduction occurs within 3-6 weeks. ${ }^{5}$ In order to prevent TB infection transmission and infection control, early diagnosis should be done and treatment should be started as soon as possible. For this reason, reliable and rapid methods are needed for TB diagnosis. Nucleic acid amplification test systems (NAATs) are able to detect TB bacilli within 3-5 hours. ${ }^{8}$ Two of these NAATs are Cobas MTB (Roche, Switzerland) and GenProbe MTD (Gen-Probe, San Diego, CA) test which are used commonly for detecting TB bacillus from clinical samples. There are some other commercial tests for this purpose. ${ }^{10-16}$ From the NAATs, Gen-Probe MTD and Cobas Amplicor MTB have been approved by US Food and Drug Administration (FDA) (Maryland, USA) for respiratory specimens from SPss in 1995 and 1998,respectively. ${ }^{17-19}$ In 1999, the FDA approved the Gen Probe MTD test for use on acidfast bacilli (AFB) smear negative sputum specimens
(SNss) obtained from the respiratory tract.18 The sensitivity and specificity of these methods vary according to used techonolgy, quality of clinical samples and laboratory experiences. The Centers for Disease Control and Prevention (CDC) (Atlanta, Georgia, USA) has proposed algorithms for the detection of Mycobacterium tuberculosis complex (MTBC) in SPss and SNss. ${ }^{17,19}$

The detection limits of these assay systems based on nucleic acid amplification for MTBC were less than 10 cells per reaction.All other laboratory NAAT results have a good sensitivity for SPss; however, for SNss, the reported sensitivity varies considerably. ${ }^{10}$ The DNA or RNA hybridization tests with labeled specific probes which have been described so far are not sensitive enough to be used for clinical specimens without culture. The polymerase chain reaction (PCR) as a rapid diagnostic technique has a potential test to overcome the limitations of sensitivity and specificity. From these systems, real-time PCR technology has replaced with the methodology of microbiological diagnosis using an automated system based on increased sensitivity. ${ }^{10-28}$

The aim of this study was to evaluate the diagnostic performance of the nine commercial NAATs (COBAS Amplicor MTB-Method A, GenProbe MTD - Method B, Cobas TaqMan MTB PCR-Method C, iCycler iQ real-time PCR-Method D, TaqMan PCR AB 5700-Method E, TaqMan PCR AB 7700-Method F, LightCycler® 480Real-Time PCR System-Method G, Rotor Gene Real Time PCR -Method H and the AdvanSure TB/NTM Real-Time PCR -Method I.

\section{METHODS}

Patient and sputum samples: One hundred-fifty sputum samples (60 SPss and 55 SNss) were obtained from Atatürk Chest Diseases and Thoracic Surgery Training and Research Hospital in Ankara, 
Turkey. It is the largest governmental chest diseases hospital located in Ankara, Turkey. It is a 600 beds, which mainly tuberculosis, non-tuberculosis and chest diseases patients. It has a full complement of services including 3 thoracic surgery services, 7 non-tuberculosis services, 4 tuberculosis services, intensive care, and emergency services. The hospital laboratory performs approximately 20000 mycobacteriology examinations (microscopy and culture) per year on specimens from in- and out patients. Each patient was identified according to the patient's history, symptoms, chest $X$ ray findings, tuberculin skin test and laboratory test results. The patients included in the study had not received antituberculous treatment and were evaluated as having suspected TB disease infection. Clinical criteria for TB infection was shown in Table 1.9,21 Sixty SPss were belong to the new pulmonary TB cases who received a confirmed diagnosis of TB based on a positive culture result. Fifty-five SNss whose specimens tested negative for acid-fast bacilli (AFB) on smear but clinically suspected TB infection. Sputum spot samples were collected triplicate before starting TB treatment. Each of the sputum samples were confirmed by direct smear microscopy separately. Then after, three sputum samples were processed and pooled, examined by smear microscopy, conventional culture, and the nine NAATs. All laboratory tests were done by an experienced laboratory expert and technologist in National Tuberculosis Reference and Research Laboratory.

Table 1. Clinical criteria for TB infection (The clinical classification of patients was carried out on the basis of information provided by the treating physicians, when available, according to the recommendations of the American Thoracic Society)

\begin{tabular}{ll}
\hline Exclusion & $\begin{array}{l}\text { Negative tuberculin skin test; smear and } \\
\text { of TB }\end{array}$ \\
& $\begin{array}{l}\text { culture negative; definitive other diagnosis } \\
\text { logically, or on the basis of clinical presen- } \\
\text { tation }\end{array}$ \\
\hline TB infection, smear and culture negative, \\
not clinically active (positive tuberculin \\
skin test and/or history of tuberculosis, de- \\
finitive other diagnosis) \\
Smear and culture negative, clinically ac- \\
tive (positive tuberculin skin test; history \\
TB infection \\
of TB; clinical, histological, or radiological \\
signs of active disease; exclusion of other \\
definitive diagnosis; improvement under \\
treatment with antitubercular chemother- \\
apy) \\
Smear negative, culture positive \\
Smear and culture positive
\end{tabular}

\section{Sample processing}

All sputum samples were decontaminated with the $\mathrm{N}$-acetyl-L-cysteine (NALC)-NaOH method in $50 \mathrm{ml}$ centrifuge tube. Two volumes of NALC-NaOH solution $(4 \% \mathrm{NaOH}, 1.45 \%$ Na-citrate, $0.5 \%$ NALC) were added to the specimen for digestion. After mixing, the mixtures were suspended at room temperature for $15 \mathrm{~min}$. After this stage, 10 volumes of 6.7 $\mathrm{mM}$ phosphate buffer ( $\mathrm{pH}$ 7.4) were added for dilution. The mixtures were centrifuged at $3,000 \times \mathrm{g}$ for $15 \mathrm{~min}$ at $4^{\circ} \mathrm{C}$. The sediment of each specimen was re-suspended in $2 \mathrm{ml}$ of the same phosphate buffer. $600 \mu$ l of the sediment was used smear microscopy and culture, $450 \mu \mathrm{l}$ for rRNA extraction (for MTD test), $800 \mu \mathrm{l}$ for DNA extraction (for eight NAATs) ${ }^{29}$.

\section{Smear examination}

All smear slides were stained by Ehrlich-Ziehl (EZN) method for detecting AFB and evaluated by an experienced microbiologist. The standard M. tuberculosis H37Rv (ATCC 27294) strain was used for quality control in the staining process..$^{9,10,30-31}$

\section{Culture}

One hundred- fifty $\mu$ l sediment was inoculated onto three Lowenstein-Jensen (LJ) slant for each sample.Slants were incubated at $37^{\circ} \mathrm{C}$ for 8 weeks and bacterial growth was controlled twice a week at the first 3 weeks and then, were examined for growth weekly. A positive culture was confirmed by EZN microscopy and identified bycolony morphology, niacin and nitrate reductase test and PCR-RFLP. ${ }^{5,10,30-33}$

\section{DNA extraction}

rRNA was extracted according to manufacturer's intstruction for GenProbe MTD. Magnapure automaticalnucleic acid extraction system (MagNA Pure LC Total Nucleic Acid Isolation Kit, Roche Diagnostics) was used for DNA extraction from processed sputum samples for the other eight NAATs. ${ }^{34,35}$

\section{NAAT tests}

All nine NAATs were performedin accordance with the manufacturer's instructions. ${ }^{36-41}$ For each NAAT; positive and negative amplification controls were used. Technical characteristics and mechanism of these systems are shown in Table 2. ${ }^{21}$ Each NAAT was performed by trained laboratory expert for test system. 
Table 2. NAATs used in this study and their target regions used for detection of MTBC

\begin{tabular}{|c|c|c|c|c|c|}
\hline Manufacturer (s) & Assay name & $\begin{array}{l}\text { Amplification } \\
\text { technology }\end{array}$ & $\begin{array}{l}\text { DNA or } \\
\text { RNA isolate } \\
\text { (for PCR) }\end{array}$ & Gene target & $\begin{array}{l}\text { Previously reported } \\
\text { sensitivity }\end{array}$ \\
\hline Roche & COBAS Amplicor MTB & $\begin{array}{l}\text { PCR colorimetric detec- } \\
\text { tion of the PCR product }\end{array}$ & $50 \mu \mathrm{l}$ & \multirow{7}{*}{ 16S rRNA } & \multirow{9}{*}{$\begin{array}{l}\cong 95 \% \text { (for } \text { SPss) } \\
\cong 66 \% \text { ( for } \text { SNss } \\
\text { clinical suspicion is } \\
\text { high) }\end{array}$} \\
\hline Gen-Probe & $\begin{array}{c}\text { Amplified Mycobac- } \\
\text { terium Tuberculosis } \\
\text { Direct Test }\end{array}$ & $\begin{array}{l}\text { Transcription-mediated, } \\
\text { Amplification, rRNA am- } \\
\text { plification method }\end{array}$ & $25 \mu \mathrm{l}$ & & \\
\hline Roche & $\begin{array}{c}\text { Cobas TaqMan MTB } \\
\text { PCR }\end{array}$ & Real-time PCR & $50 \mu \mathrm{l}$ & & \\
\hline BIO-RAD & $\begin{array}{c}\text { iCycler iQ real-time } \\
\text { PCR }\end{array}$ & Real-time PCR & $2 \mu \mathrm{l}$ & & \\
\hline $\begin{array}{l}\text { Applied Biosys- } \\
\text { tems } 5700\end{array}$ & TaqMan PCR & Real-time PCR & $5 \mu \mathrm{l}$ & & \\
\hline $\begin{array}{l}\text { Applied Biosys- } \\
\text { tems) } 7700\end{array}$ & TaqMan PCR & Real-time PCR & $5 \mu l$ & & \\
\hline Roche & $\begin{array}{l}\text { LightCycler® } 480 \text { Re- } \\
\text { al-Time PCR System }\end{array}$ & Real-time PCR & $2 \mu l$ & & \\
\hline Artus & $\begin{array}{l}\text { Rotor Gene Real Time } \\
\text { PCR }\end{array}$ & Real-time PCR & $5 \mu \mathrm{l}$ & 159 bp region & \\
\hline LG Life Science & $\begin{array}{c}\text { AdvanSure TB/NTM } \\
\text { Real-Time PCR }\end{array}$ & Real-time PCR & $2 \mu \mathrm{l}$ & $\begin{array}{l}\text { IS6110 and } \\
\text { ITS region }\end{array}$ & \\
\hline
\end{tabular}

\section{Ethics Statement}

This study was approved by Atatürk Chest Diseases and Thoracic Surgery Training and Research Hospital Clinical Research Ethics Committee to collect patient sample and reviewed by Refik Saydam National Public Health Agency reviewer board for laboratory study. Written informed consent was obtained from all patients.

\section{Statistical Analysis}

The sensitivity, specificity, positive predictive value (PPV), and negative predictive value (NPV) of the nine NAATs were calculated by using the culture results as the reference standards (38). Statistical comparisons of the nine methods were performed by using the chi-square test; a $P$ value of $<0.05$ was considered significant the analysis was performed by using of SPSS, version 14.0 (SPSS). ${ }^{42}$

\section{RESULTS}

A total of 115 sputum samples (60 SP and $55 \mathrm{SN}$ ) collected from 115 patients were tested in this study. All samples were examined by smear examination, LJ culture and nine NAATs. Of 60 SPss were smear positive, culture positive and clinical data positive. Thirteen of 55 SNss were culture positive (Table 3).
Rests of SNss (42/55) were found negative for culture and clinical data but tuberculin skin test result was higher than 15 millimeters for each patient. The rest of SNss (42/55) were clinically positive. When LJ culture results were taken as gold standard; the positivity rates of the method $A, B, C, D, E, F, G$, $\mathrm{H}$ and I were was found $98.33 \%, 93.33 \%, 96.7 \%$, $100 \%, 93.3 \%, 100 \%, 100 \%, 100 \%$ and $100 \%$ respectively for SPss. It was found as $53.84 \%(7 / 13)$ for methods A, B, D, E, G, I; 38.5\% (5/13) for methods $C$ and $H, 61.5 \%(8 / 13)$ for method $F$ in SNss (Table 3 ). When LJ culture results were accepted as a reference method, the sensitivity rates of the methods A, B, C, D, E, F, G, H, I were $100 \%$ for SPss. The sensitivity was $53.8 \%$ for the methods $A, B, D, E, G$ and $\mathrm{I} ; 38.5 \%$ for the method $\mathrm{C}$ and $\mathrm{H}$; $61.5 \%$ for the method $F$ for the method I in SNss. There were no statistical significant differences between the nine NAATs $(p \geq 0.05)$. The specificity was $100 \%$ for all nine NAATs in SNss. Statistical analysis showed that there were no significant differences among the nine NAATs. The $P$ values were 0.145 for smear-positive plus culture-positive specimens, 0.490 for smear-negative but culture-positive specimens, and 0.220 for smear-negative plus culturenegative specimens. 
Table 3. The positivity rate of the nine NAATs systems in smear positive and smear negative sputum samples when culture results were taken as gold standards

\begin{tabular}{lccccccccc}
\hline \multirow{2}{*}{ Specimens } & \multicolumn{2}{l}{ Method A } & Method B & Method C & Method D & \multicolumn{1}{c}{ Method E } & Method F & Method G & Method H Method I \\
\cline { 2 - 10 } & $\mathrm{P}(\%)$ & $\mathrm{P}(\%)$ & $\mathrm{P}(\%)$ & $\mathrm{P}(\%)$ & $\mathrm{P}(\%)$ & $\mathrm{P}(\%)$ & $\mathrm{P}(\%)$ & $\mathrm{P}(\%)$ & $\mathrm{P}(\%)$ \\
$\mathrm{SP}(\mathrm{n}: 60)$ & $59(98.3)$ & $56(93.3)$ & $58(96.7)$ & $60(100)$ & $56(93.3)$ & $60(100)$ & $60(100)$ & $60(100)$ & $60(100)$ \\
SN (n:13) & $7(53.8)$ & $7(53.8)$ & $5(38.5)$ & $7(53.8)$ & $7(53.8)$ & $8(61.5)$ & $7(53.8)$ & $5(38.5)$ & $7(53.8)$ \\
\hline
\end{tabular}

Method A=COBAS Amplicor MTB, Method B=GenProbe MTD, Method C=Cobas TaqMan MTB PCR, Method D= iCycler iQ real-time PCR (BIO-RAD), Method E= TaqMan PCR Applied Biosystems 5700, Method F= TaqMan PCR Applied Biosystems) 7700, Method G= LightCycler® 480 Real-Time PCR System (Roche), Method H= Rotor Gene Real Time PCR, Method I= AdvanSure TB/NTM RealTime PCR, $\mathrm{P}=$ Positive, $\mathrm{SP}=\mathrm{Smear}$ positive, $\mathrm{SN}=\mathrm{Smear}$ negative

Table 4. The sensitivity, specifity, PPV and NPV of nine NAATs systems in smear positive and smear negative sputum samples culture results were taken as gold standard

\begin{tabular}{|c|c|c|c|c|c|c|c|c|c|c|}
\hline \multicolumn{2}{|c|}{ Specimen } & $\begin{array}{c}\text { Method A } \\
(\%)\end{array}$ & $\begin{array}{l}\text { Method B } \\
(\%)\end{array}$ & $\begin{array}{c}\text { Method C } \\
(\%)\end{array}$ & $\begin{array}{l}\text { Method D } \\
(\%)\end{array}$ & $\begin{array}{l}\text { Method E } \\
(\%)\end{array}$ & $\begin{array}{l}\text { Method F } \\
(\%)\end{array}$ & $\begin{array}{c}\text { Method G } \\
(\%)\end{array}$ & $\begin{array}{l}\text { Method H } \\
(\%)\end{array}$ & $\begin{array}{l}\text { Method I } \\
(\%)\end{array}$ \\
\hline \multirow{4}{*}{ 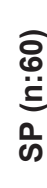 } & Sensitivity & 98.3 & 93.3 & 96.7 & 100 & 93.3 & 100 & 100 & 100 & 100 \\
\hline & Specificity & - & - & - & - & - & - & - & - & - \\
\hline & PPV & 100 & 100 & 100 & 100 & 100 & 100 & 100 & 100 & 100 \\
\hline & NPV & - & - & - & - & - & - & - & - & - \\
\hline \multirow{4}{*}{ 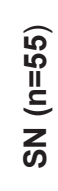 } & Sensitivity & 53.8 & 53.8 & 38.5 & 53.8 & 53.8 & 61.5 & 53.8 & 38.5 & 53.8 \\
\hline & Specificity & 100 & 100 & 100 & 100 & 100 & 100 & 100 & 100 & 100 \\
\hline & PPV & 100 & 100 & 100 & 100 & 100 & 100 & 100 & 100 & 100 \\
\hline & NPV & 87.5 & 87.5 & 84 & 87.5 & 87.5 & 89.36 & 87.5 & 84 & 87.5 \\
\hline
\end{tabular}

Method $A=$ COBAS Amplicor MTB, Method B=GenProbe MTD, Method C=Cobas TaqMan MTB PCR, Method D= iCycler iQ real-time PCR (BIO-RAD), Method E= TaqMan PCR Applied Biosystems 5700, Method F= TaqMan PCR Applied Biosystems) 7700, Method G= LightCycler ${ }^{\circledR} 480$ Real-Time PCR System (Roche), Method H= Rotor Gene Real Time PCR, Method I= AdvanSure TB/NTM RealTime $\mathrm{PCR}, \mathrm{SP}=\mathrm{Smear}$ positive, $\mathrm{SN}=$ Smear negative, $\mathrm{PPV}=$ Positive predictive value, NPV=Negative predictive value

\section{DISCUSSION}

In recent years, many NAATs were developed for the rapid diagnosis of MTBC from clinical samples and determination of drug resistance. Sensitivity and specificity rates of these tests were changing to type patient group, quality of the clinical samples, processing method of samples, DNA isolation and reference methods. ${ }^{11-16}$ NAATs have a good sensitivity for smear-positive specimens. However; the sensitivity rates have been varied considerably for SNss in the reported studies. ${ }^{20-28}$ For most commercial tests, the assay sensitivities (87.5\%$100 \%$ ) seem to be satisfactory for AFB SPss, but the sensitivities $(50.0 \%$ to $70.8 \%$ ) varied greatly for AFB SNss. ${ }^{11-16}$ Within these NAATs; Cobas Amplicor MTB and GenProbe MTD systems were commonly used for rapid diagnosis of MTBC in sputum samples..$^{9,11-21}$ Recently, several commercial NAAT system based on real-time PCR is used for routine diagnosis. Real-time PCR has several advantages, such as a short turnaround time, a low contamination rate due to the use of a closed system and the ability to quantify the bacterial load. ${ }^{19-26}$ In our study, we aimed to evaluate the nine NAATs in their ability to detect MTBC in SPss and SNss. This sensitivity value $(100 \%)$ was comparable with the reported studies. ${ }^{11-16,21-27,43-46}$ For detection of MTBC in SNss, our results were comparable with the results obtained by published data. The sensitivity of $\mathrm{C}$ and $\mathrm{H}$ method was the lowest among those $(51 \%$ to $71.7 \%$; average, $59.5 \%$ ) reported for the NAATs. ${ }^{11-16,} 21-27,43-$ ${ }^{46}$ For SNss, the sensitivity rates of the nine NAAT methods were correlating with the results obtained by published data. The sensitivity rates were very low for SNss. The specifity and NPV value could not be determined due to the absence of the negative sample result group for SPSss.

Negative results obtained from culture-positive specimens by molecular amplification assays are normally explained by a low load of mycobacteria and an unequal distribution of mycobacteria in the test specimens. ${ }^{21}$ It was noted that the extraordinary low sensitivity of the nine NAATS for smear negative samples comparison with published studies. 
Due to the low sensitivity to SNss seems to lower the effect of the nine NAATs. The low sensitivity for smear-negative specimens seems to be the nine NAATs ineffective. Negative results obtained from culture-positive specimens by molecular amplification assays are normally explained by a low load of mycobacteria and an unequal distribution of mycobacteria in the test specimens. The overall specificity of the Cobas TaqMan MTB, GenProbe MTD, Cobas TaqMan MTB PCR, LightCycler® 480RealTime PCR, Rotor Gene Real Time PCR, AdvanSure TB/NTM Real-Time PCR were $100 \%$; this value was comparable to those $(91.3 \%$ to $100 \%)$ reported for the Cobas Amplicor MTB assay. 11,15,16,21 The specifity and NPV values were not calculated, because of all samples were culture positive in SPss. While specifity and PPV values of nine NAATs were found $100 \%$, the sensitivity and NPV values were differ as NAAT method in SNss. In our study, the lowest sensitivity for SNss was detected with method $C$ and $\mathrm{H}(38.46 \%)$. According to our experience, the nine NAAT systems do not have a prominent ability to detect lower loads of MTBC in SNss. No significant differences were observed among the results of the nine NAATs, which are acceptable for direct detection of M. tuberculosis complex in SNss. As a result, the nine NAATS systems performance was found ineffective for SNss. Our study showed lower sensitivity than the previously reported data, especially for the Cobas Amplicor PCR. Until now, the diagnostic sensitivity of commercially available kits, including the Cobas Amplicor PCR, for detection of M. tuberculosis had been reported to be over $80 \% .{ }^{11,15,16,21}$ The performance of the nine NAAT system can use only SPss. As bacillus amount is very low in SNss; determination capacity of molecular methods is also low.

\section{CONCLUSION}

Due to the results of this study and previous reports, it is obvious that molecular methods are still not as sensitive as culture. The major strengths and weaknesses of a NAAT system should be entirely understood before the system is adopted in the routine laboratory. NAATs should be interpreted within the context of the patient's signs and symptoms, and should always be performed in conjunction with AFB smear and culture. As a result, nine NAATs might be useful for detecting MTBC from SPss, but not effective for SNss.

\section{Acknowledgement}

This study has been presented as a poster at $33^{\text {rd }}$ Annual Congress of the European Society of Mycobacteriology, 01-04 July 2012, Brasov, Romania.

\section{REFERENCES}

1. T.C.Sağlık Bakanlığı Verem Savaş Daire Başkanlığı, Türkiye'de Verem Savaşı 2011 Raporu 5-9.

2. International Standards for Tuberculosis Care. 2013; Available from: http://www.who.int/tb/publications/2006/istc_report. pdf, accessed on March 6.

3. World Health Organization Global tuberculosis control: surveillance,planning, financing 2008;1-2.

4. Gebre N. Improved microscopical diagnosis of PTB in developing countries. Trans Royal Soc Trap Med Hyg 1995 89:191-193.

5. World Health Organization.Tuberculosis Diagnostic Workshop: Product Development guidelines 1997;21-24.

6. World Health Organization. Laboratory services in tuberculosis control part III culture. Global Tuberculosis Programme 1998; 47-52.

7. Lambi EA. Medium selection and incubation for the isolation of Mycobacteria, In: Isenberg HD, editor. Clinical microbiology procedures handbook. Vol. 1. Washington, D.C. American Society for Microbiology. 1993; 3.6.1-3.6.8.

8. Metchock BG, Nolte FS, Wallace Jr RJ. Mycobacterium. In: Murray PR, Baron EJ, Pfaller MA et al, editors. Manual of clinical microbiology $7^{\text {th }}$ ed. Washington, D.C. American Society for Microbiology 1999;399-437.

9. Diagnostic standards and classification of tuberculosis (1990) American Thoracic Society Am Rev Respir Dis 1990; 142:725-735.

10. Waard JH, Robledo J.Conventional diagnostic methods. In: Palomino JC, Leão SC, Ritacco V (editors). Tuberculosis (Available from: www.TuberculosisTextbook.com). 2007; 12:401-424.

11. Bogard M, Vincelette J, Antinozzi R, et al. Multicenter study of a commercial, automated polymerase chain reaction system for the rapid detection of Mycobacterium tuberculosis in respiratory specimens in routine clinical practice. Eur J Clin Microbiol Infect Dis 2001; 20:724-731.

12. Greco S, Girardi E, Navarra A, Saltini C. Current evidence on diagnostic accuracy of commercially based nucleic acid amplification tests for the diagnosis of pulmonary tuberculosis. Thorax 2006; 61:783-790.

13. Balasingham SV, Davidsen TI, Szpinda SA, Tonjum T. Molecular diagnostics in tuberculosis: basis and implications for therapy. Mol Diagn Ther 2009; 13:137-151.

14. Laraque F, Griggs A, Slopen M, Munsiff SS. Performance of nucleic acid amplification tests for diagnosis of tuberculosis in a large urban setting. Clin Infect Dis 2009; 49:46-54.

15. Ling DI, Flores LL, Riley LW, Pai M. Commercial nucleic-acid amplification tests for diagnosis of pulmonary tuberculosis in respiratory specimens: meta-analysis and meta-regression PLoS One 2008; 3:e1536.

16. Noordhoek GT, Mulder S, Wallace P, van Loon AM. Multicentre quality control study for detection of Mycobacterium tuberculosis in clinical samples by nucleic amplification methods.Clin Microbiol Infect 2004;10:295-301. 
17. World Health Organization.Tuberculosis Diagnostic Technology Landscape 2012;19-23.

18. Centers for Disease Control and Prevention (CDC). Update: nucleic acid amplification tests for tuberculosis. MMWR Morb Mortal Wkly Rep 2000; 49:593-594.

19. World Health Organization. New technologies for tuberculosis control: a framework for their adoption, introduction and implementation; 2007.

20. Centers for Disease Control and Prevention (CDC). Updated guidelines for the use of nucleic acid amplification tests in the diagnosis of tuberculosis. MMWR 2009;58:7-10.

21 .Reischl U, Lehn N, Wolf H, Naumann L. Clinical evaluation of the automated COBAS AMPLICOR MTB assay for testing respiratory and non-respiratory specimens. J Clin Microbiol1998; 36:2853-60.

22. Chang HE, Heo SR, Yoo KC, et al. Detection of Mycobacterium tuberculosis complex using real-time polymerase chain reaction. Korean J Lab Med 2008; 28:103-108.

23. Ortu S, Molicotti P, Sechi LA, et al. Rapid detection and identification of Mycobacterium tuberculosis by Real Time PCR and Bactec 960 MIGT. New Microbiol 2006;29: 75-80.

24. Jung CL, Kim MK, Seo DC, Lee MA. Clinical usefulness of real-time PCR and amplicor MTB PCR assays for diagnosis of tuberculosis. Korean J Clin Microbiol. 2008; 11:29-33.

25. Piersimoni C, Scarparo C. Relevance of commercial amplification methods for direct detection of Mycobacterium tuberculosis complex in clinical samples. J Clin Microbiol 2003; 41:5355-5365.

26. Dinnes, J., et al.A systematic review of rapid diagnostic tests for the detection of tuberculosis infection. Health Technol Assess 2006;11:119-196.

27. Flores LL, Pai M, M. Colford J, et al. In-house nucleic acid amplification tests for the detection of Mycobacterium tuberculosisin sputum specimens: meta-analysis and metaregression. BMC Microbiol 2005; 5:55.

28. Tan WY, Stratton CW. Diagnosis of Mycobacterium tuberculosis. Advanced techniques in diagnostic microbiology, $2^{\text {nd }}$ Edition. Springer Newyork Heidelberg Dordrecht, London 2006;567.

29. Kubica GPW, Dye E, Cohn ML, Middlebrook G. Sputum digestion and decontamination with $\mathrm{N}$-acetyl-Lcysteine- sodium hydroxide for culture of mycobacteria. Am Rev Respir Dis 1963; 87:775-779.

30. Waard JH, Robledo. Conventional diagnostic methods. In: Palomino JC, Leão SC, Ritacco V (editors). Tuberculosis (Available from: www.TuberculosisTextbook.com). 2007; 12:401-424.

31. Tuberculosis Division, International Union Against Tuberculosis and Lung Disease. Tuberculosis bacteriology- priorities and indications in high prevalence countries: position of the technical staff of the Tuberculosis Division of the International Union Against. Int J Tuberc Lung Dis 2005; 9:355-361.

32. Telenti A, Marchesi F, Balz M, et al. Rapid identification of mycobacteria to the species level by polymerase chain reaction and restriction enzyme analysis. J Clin Microbiol 1993; 31:175-178.

33. Vincent V, Brown-Elliott BA, Jost KC, Wallace RJ. Mycobacterium: phenotypic and genotypic identification, In Murray $P$ R., Baron E. J., Baron E. J., Pfaller M. A., Yolken R. H., editors. (ed.), Manual of clinical microbiology, $8^{\text {th }}$ ed. American Society for Microbiology, Washington, DC.2003; p. 560-584.

34. Amplied MTD Test (amplified Mycobacterium tuberculosis direct test for in vitro diagnostic use) [package insert] San Diego, CA: Gen-Probe 2001

35. MagNA Pure LC Total Nucleic Acid Isolation Kit (Available from:www.http://www.roche-applied-science.com/shop/products/magna-pure-lc-total-nucleic- acid-isolation-kit)

36. Roche Molecular Systems, Inc, COBAS TaqMan MTB test (2007) Roche Molecular Systems, Inc., Branchburg, NJ.

37. Biorad iCycler $\mathrm{iQ}^{\mathrm{TM}}$. Real-Time PCR Detection System. Instruction Manual. Catalog Number: 170-8740.

38. Applied Biosystems, TaqMan® Universal PCR Master Mix, Instruction Manual. Available from: www.appliedbiosystems. com

39. The LightCycler® 480 Real-Time PCR System Guide (2008) Roche Applied Science, 68298 Mannheim, Germany, Roche Diagnostics.

40. Rotor-Gene $₫ Q$ and artus $₫$ PCR Kits -Pure Pathogen Detection (2010) Available from: www.qiagen.com

41. AdvanSure TB/NTM real-time PCR kit procedures, LG Life Sciences, Seul, Korea

42. Gardner MJ, Altman DG (ed.) Statistics with confidence. BMJ Publishing Group, London, United Kingdom. 1989.

43. Gamboa F, Manterola JM, Lonca J, et al. Comparative evaluation of two commercial assays for direct detection of Mycobacterium tuberculosis in respiratory specimens. Eur $\mathrm{J}$ Clin Microbiol Infect Dis 1998; 17:151-156.

44. Kim YJ, Park MY, Kim SY, et al. Evaluation of the performances of advanSure TB/NTM real time PCR Kit for detection of mycobacteria in respiratory specimens. Korean $\mathrm{J}$ Lab Med 2008; 28:34-38.

45. Yang YC, Lu PL, Huang SC, et al. Evaluation of the Cobas Taq Man MTB test for direct detection of Mycobacterium tuberculosis complex in respiratory specimens. J Clin Microbiol 2011; 49(3):797-801. doi: 10.1128/JCM.01839-10.

46. Kim JH, Kim YJ, Ki CS, et al. Evaluation of COBAS TaqMan MTB PCR for detection of Mycobacterium tuberculosis. J Clin Microbiol 2011; 49:173-176. 